\title{
Pengendalian Kualitas Gula Kristal Putih (GKP) di PG Tjoekir Jombang Menggunakan Diagram Kontrol Multivariat Berbasis Time Series
}

\author{
${ }^{1}$ Muhammad Salam Taufiqi dan ${ }^{2}$ Diaz Fitra Aksioma \\ Departemen Statistika, Fakultas Matematika, Komputasi dan Sains Data \\ Institut Teknologi Sepuluh Nopember (ITS) \\ Jl. Arief Rahman Hakim, Surabaya 60111 Indonesia \\ e-mail: ${ }^{1}$ salam16.mhs@statistika.its.ac.id dan ${ }^{2}$ diaz_fa@statistika.its.ac.id
}

\begin{abstract}
Abstrak - PG Tjoekir Jombang merupakan salah satu unit usaha dari PTPN X yang bergerak pada bidang pengadaan gula. Salah satu produk utama yang dihasilkan oleh PG Tjoekir Jombang adalah Gula kristal putih yang harus memenuhi kriteria Standar Nasional Indonesia (SNI). Karakteristik kualitas yang digunakan adalah warna larutan gula (ICUMSA) dan Besar Jenis Butir. Kedua karakteristik tersebut memiliki hubungan yaitu jika semakin kecil BJB maka ICUMSA akan semakin putih. hal itu menjelaskan jika semakin putih maka kualitas gula kristal putih semakin baik. Proses monitoring kualitas gula kristal putih dilakukan untuk menjaga kualitas dari gula yang dihasilkan oleh PG Tjoekir Jombang. Pengendalian kualitas menggunakan diagram kontrol multivariat berbasis time series lebih sesuai digunakan karena asumsi yang harus terpenuhi adalah tidak adanya autokorelasi antar pengamatan. Diagram kontrol dibuat berdasarkan residual dari model terbaik. Model terbaik yang diperoleh yaitu dengan menggunakan model VAR (3). Hasil diagram kontrol menunjukkan bahwa variabilitas dan rata-rata proses belum terkendali secara statistik. Salah satu penyebabnya adalah terjadinya kerusakan pada mesin dikarenakan setting mesin dan usia mesin saat sedang beroperasi, faktor tenaga kerja yang kurang teliti dan beberapa faktor yang lainnya.
\end{abstract}

Kata Kunci - Diagram Kontrol, Multivariate, Residual, Time Series, VAR.

\section{PENDAHULUAN}

Kebutuhan gula nasional tahun 2017 mencapai 5,7 juta ton K dengan 3,2 juta ton kebutuhan industry dan sisanya untuk rumah tangga[1]. PTPN sebagi salah satu perusahaan yang memiliki tanggung jawab pengoperasian dan pengadaan gula di beberapa daerah di provinsi Jawa Timur belum mampu memnuhi kebutuhan nasional. PG Tjoekir Jombang sebagai salah satu unit usaha milik PTPN X memiliki tugas untuk melakukan giling tebu dan dapat mencapai target produksi yang telah ditetapkan. PG Tjoekir Jombang sendiri memiliki kapasitas produksi sebesar 4.200 TCD. Produk utama yang dihasilkan oleh pabrik gula adalah gula kristal putih (GKP) yang akan di pasarkan kepada industri makanan dan konsumsi rumah tangga. GKP yang dihasilkan harus memeui standar kualitas yang telah ditetapkan oleh Badan Standard Nasional
(BSN). Menurut permendag tahun 2016 yang mengatur tentang pengawasan SNI wajib terhadap barang produksi dalam negri atau impor. Berdasarkan peraturan tersebut PG Tjoekir Jombang harus memperhatikan kualitas GKP yang dihasilkan agar tetap bersaing di pasar nasional. Karakteristik kualitas GKP ditentukan oleh warna larutan gula (ICUMSA) dan besar jenis butir (BJB). Menurut Payne (1982) semakin kecil ukuran BJB, maka kristal gula akan semakin putih[2]. Karakteristik kualitas pada GKP yag meliputi warna larutan gula (ICUMSA) dan BJB harus memenuhi kriteria yang telah ditetapkan oleh BSN[3]. Penelitian serupa pernah dilakukan oleh Widiaswanti (2014) dengan menggunakan 3 variabel yaitu ICUMSA, BJB dan Kadar air [4].

Diagram kontrol merupakan salah satu alat statistik yang dapat digunakan dalam mengendalikan kualitas suatu karakteristik. Diagram kontrol multivariat digunakan apabila terdapat lebih dari satu karakteristik kualitas dimana antar karakteristik kualitas saling berkorelasi atau terjadi autokorelasi. Pada kasus ini diketahui bahwa bahan dasar dari pembuatan gula kristal putih adalah nira yang merupakan zat cair, sehingga diduga terdapat depedensi antar pengamatan karena dalam proses pembuatannya dilakukan secara terus menerus. Asumsi yang harus terpenuhi ketika membuat diagram kontrol multivariat $\mathrm{T}^{2}$ Hotelling adalah antar variabel berkorelasi, dan antar pengamatan idependen (tidak ada autokorelasi) serta berdistribusi normal [5]. Autokorelasi antar observasi memberikan efek pada diagram kontrol konvensioal, maka dari itu digunakan pendekatan umum untuk membentuk diagram kontrol yang memiliki autokorelasi dengan menggunakan metode time series [6].

Penelitian sebelumnya yang berkaitan dengan diagram kontrol multivariate untuk data berautokorelasi dengan menggunakan pendekatan time series dilakukan oleh Pan dan Jarret (2006) yang meneliti diagram kontrol VAR untuk pengendalian proses multivariat (cross-sectional) dari data yang berautokorelasi[7]. Penelituin lain yang berkaitan dengan pabrik gula dilakukan oleh putri (2015) menganalisis pengendalian kualitas tetes produksi PG pesantren Baru Kediri menggunakan diagram kontrol multivariat berbasis time series [8].

Berdasarkan uraian yang telah dijelaskan sebelumnya, maka dalam penelitian ini akan dilakukan penelitian terkait dengan pengendalian kualitas gula kristal putih produksi PG 
Tjoekir Jombang secara multivariate berbasis model time series. Penelitian ini diharapkan mampu memberikan informasi bagi PG Tjoekir Jombang dalam melakukan proses produksi gula kristal putih memperhatikan faktor ketidaksesuaian proses dan melakukan perbaikan.

\section{TINJAUAN PUSTAKA}

\section{A. Model Vektor Autoregressive (VAR)}

Model vektor Autoregressive adalah metode peramalan dengan mebentuk model-model sebuah vektor dimana variabel-variabel saling mempengaruhi. Bentuk umum VAR (p) ialah sebagai berikut[9].

$$
\dot{\mathbf{X}}_{\mathbf{t}}=\boldsymbol{\Phi}_{1} \dot{\mathbf{X}}_{\mathrm{t}-1}+\ldots-\boldsymbol{\Phi}_{\mathbf{P}} \dot{\mathbf{X}}_{\mathrm{t}-\mathrm{p}}+\mathbf{a}_{\mathbf{t}}
$$

\section{B. Digram Kontrol $M$}

Diagram kontrol $\mathrm{M}$ dapat digunakan untuk memonitor variabilitas proses secara multivariat utuk pengamatan individu yang didasarkan pada successive difference [10]. Successive difference yaitu selisih antar vektor pengamatan secara berturut-turut dan digunakan dalam menghitung nilai statistiknya berdistribusi $\mathrm{N}_{\mathrm{p}}(0, \Sigma)$ sebagai berikut.

$$
\mathbf{W}=\left[\begin{array}{c}
w_{1}^{\prime} \\
w_{2}^{\prime} \\
\vdots \\
w_{n-1}^{\prime}
\end{array}\right]=\left[\begin{array}{c}
\left(\hat{a}_{2}-\hat{a}_{1}\right)^{\prime} \\
\left(\hat{a}_{3}-\hat{a}_{2}\right)^{\prime} \\
\vdots \\
\left(\hat{a}_{n}-\hat{a}_{n-1}\right)^{\prime}
\end{array}\right] \text {,dimana } \mathrm{t}=1,2, \ldots, \mathrm{n}-1
$$

Didapatkan statistik uji untuk diagram kontrol $M$ adalah sebagai berikut.

$$
\mathbf{M}_{t}=\frac{1}{2}\left(\hat{\mathbf{a}}_{\mathbf{t}+\mathbf{1}}-\hat{\mathbf{a}}_{\mathbf{t}}\right)^{\prime} \boldsymbol{\Sigma}^{-1}\left(\hat{\mathbf{a}}_{\mathbf{t}+\mathbf{1}}-\hat{\mathbf{a}}_{\mathbf{t}}\right)
$$

Batas kendali diagram kontrol $M$ adalah sebagai berikut.

$$
\begin{aligned}
& \mathrm{BKA}=\chi_{p, \alpha / 2}^{2} \\
& \mathrm{BKB}=\chi_{p, 1-\alpha / 2}^{2}
\end{aligned}
$$

Dimana $p$ adalah banyaknya karakteristik kualitas.

\section{Diagram Kontrol $T^{2}$ Hotelling Individu}

Diagram kontrol $\mathrm{T}^{2}$ Hotelling merupakan diagram kontrol yang digunakan untuk pengendalian rata - rata suatu proses yang terdiri dari beberapa karakteristik kualitas [5]. Matriks varians kovarians menggunakan metode successive difference (menggunakan selisish dua vektor yang berurutan). Persamaan yang digunakan untuk memperoleh matriks varians koarians adalah sebagai berikut.

$$
\mathbf{V}=\left[\begin{array}{c}
v_{1}^{\prime} \\
v_{2}^{\prime} \\
\vdots \\
v_{n-1}^{\prime}
\end{array}\right]=\left[\begin{array}{c}
\left(\hat{a}_{2}-\hat{a}_{1}\right)^{\prime} \\
\left(\hat{a}_{3}-\hat{a}_{2}\right)^{\prime} \\
\vdots \\
\left(\hat{a}_{n}-\hat{a}_{n-1}\right)^{\prime}
\end{array}\right] \text {, dimana } \mathrm{t}=1,2, \ldots, \mathrm{n}-1
$$

Dimana $v$ merupakan vektor selisih antara vektor data ke-t dan vektor data ke $\mathrm{t}+1$. Kemudian matriks kovarians dapat dihitung dengan menggunakan persamaan berikut.

$$
\mathbf{S}_{1}=\frac{1}{2} \frac{\mathbf{V}^{\prime} \mathbf{V}}{(n-1)}
$$

nilai statistik $\mathrm{T}^{2}$ hotelling individu dapat dihitung dengan menggunakan persamaan berikut.

$$
\mathrm{T}_{\mathrm{t}}^{2}=\left(\hat{\mathbf{a}}_{\mathbf{t}}-\overline{\hat{\mathbf{a}}}\right)^{\prime} \mathrm{S}_{2}^{-1}\left(\hat{\mathbf{a}}_{\mathrm{t}}-\overline{\hat{\mathbf{a}}}\right), \quad \mathrm{t}=1,2, \ldots, \mathrm{n}
$$

Diagram kendali $\mathrm{T}^{2}$ Hotelling Individu memiliki batasan kontol untuk fase I sebagai berikut.

$$
\begin{aligned}
& \mathrm{BKA}=\frac{(n-1)^{2}}{n} \beta_{\alpha, p / 2,(n-p-1) / 2} \\
& \mathrm{BKB}=0
\end{aligned}
$$

Keterangan $: \mathrm{n}=$ banyaknya pengamatan, $\mathrm{t}=1,2,3, \ldots, \mathrm{n}$ p=banyaknya karakteristik kualitas (variabel)

\section{Proses Produksi Gula Di PG Tjoekir Jombang}

Proses produksi di PG Tjoekir Jombang tidak berbeda dengan pabrik gula yang lain. Berikut ini adalah gambaran proses produksi gula di PG Tjoekir Jombang.

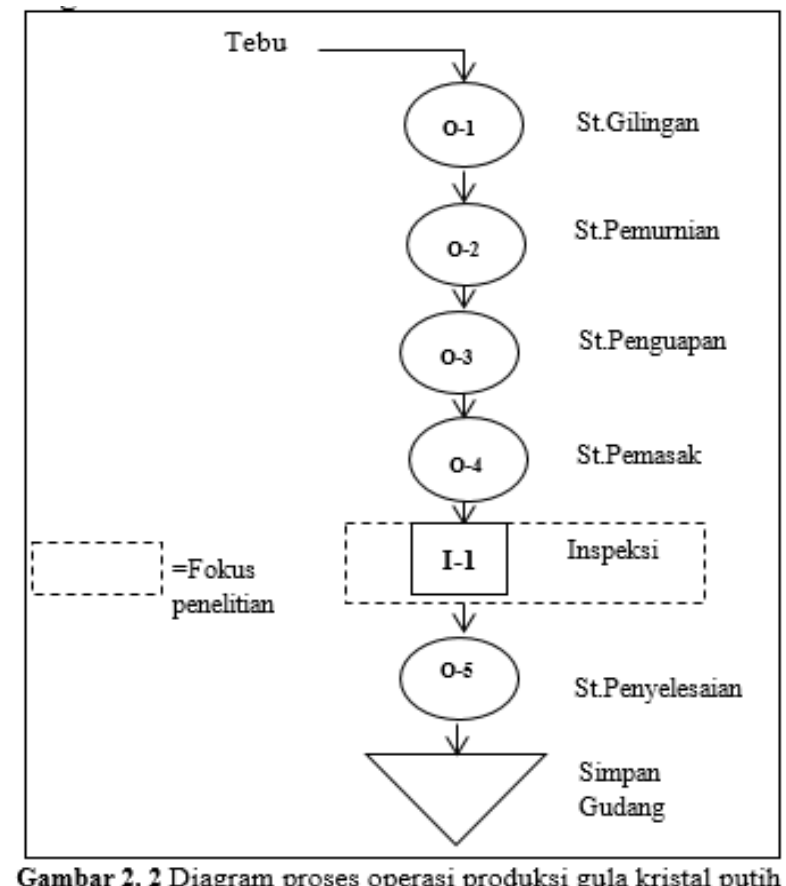

\section{METODOLOGI PENELITIAN}

\section{A. Sumber Data dan Variabel Penelitian}

Data yang digunakan dalam penelitian ini merupkan data sekunder yang didapatkan dari divisi quality assurance (QA) PG Tjoekir Jombang. Data yang diguanakan adalah data pada musim giling tahun 2017 yang terjadi pada bulan Juli sampai Oktober. Sampl dimabil kurang lebih 300 gram dan pengambilan sampel dilakukan setiap 8 jam sekali yaitu pada pukul 07.00 WIB (shift 1), pukul 16.00 WIB (Shift 2), dan pukul 00.00 WIB (Shift 3), sehingga dalam 1 hari diambil sampel sebanyak 3. Variabel yang digunakan dalam penelitian ini ditabelkan pada Tabel 1. 
Tabel 1. Variabel Penelitian

\begin{tabular}{cccc}
\hline Variabel & Keterangan & Satuan & Batas Spesifikasi \\
\hline $\mathrm{X}_{1}$ & Warna larutan gula & $\mathrm{IU}$ & $81-200$ \\
$\mathrm{X}_{2}$ & (ICUMSA) & $\mathrm{mm}$ & $0,8-1,2$ \\
\hline
\end{tabular}

Berikut ini adalah penjelasan mengenai karakteristik kualitas gula kristal putih.

1. ICUMSA

Warna larutan gula atau yang biasa disebut ICUMSA. ICUMSA merupakan zat warna yang terkandung dalam butir kristal gula. Semakin kecil ICUMSA-nya, mutu gula cenderung makin baik dan warna juga makin putih cermerlang.

2. Berat Jenis Butir

Berat Jenis Butir (BJB) merupakan ukuran rata-rata butir kristal gula yang dinyatakan dalam mm. Semakin tinggi tingkat keseragaman kristal, maka kualitas kristal gula semakin baik. Hal ini menunjukkan bahwa apabila besar jenis butir semakin kecil sesuai dengan spesifikasi dari SNI, maka warna larutan gula (ICUMSA) semakin putih.

Tabel 2. Struktur Data

\begin{tabular}{|c|c|c|c|}
\hline \multirow[t]{2}{*}{ Fase } & \multirow[t]{2}{*}{$\begin{array}{c}\text { Pengamatan } \\
\text { ke- }\end{array}$} & \multicolumn{2}{|c|}{$\begin{array}{c}\text { Karakteristik } \\
\text { Kualitas }\end{array}$} \\
\hline & & ICUMSA & BJB \\
\hline \multirow{4}{*}{ Satu } & 1 & $\hat{a}_{11}$ & $\hat{a}_{12}$ \\
\hline & 2 & $\hat{a}_{21}$ & $\hat{a}_{22}$ \\
\hline & $\vdots$ & $\vdots$ & $\vdots$ \\
\hline & $\mathrm{n}_{1}$ & $\hat{a}_{n_{1} 1}$ & $\hat{a}_{n_{1} 2}$ \\
\hline
\end{tabular}

\section{B. Langkah Analisis}

Langkah-langkah analisis yang akan dilakukan berdasarkan dengan tujuan adalah sebagai berikut.

1. Eksplorasi data karakteristik kualitas gula kristal putih

2. Cek autokorelasi data

3. Melakukan pemodelan VAR

a. Menguji stasioneritas data dalam mean dan

b. Menguji stasioneritas data dalam varian.

c. Mengidentifikasi order model VAR.

d. Estimasi parameter model

e. Pemeriiksaan diagnosa meliputi signifikansi parameter, white noise dan distribusi multivariat normal.

4. Pengujian asumsi dependesi residual antar variabel

5. Membuat diagram kontrol $\mathrm{M}$

6. Membua diagram kontrol $\mathrm{T}^{2}$ Hotelling individu.

7. Identifikasi masalah pada proses.

8. Menarik kesimpulan dan saran.

\section{ANALISIS DAN PEMBAHASAN}

\section{A. Eksplorsi karakteristik Kualitas Gula Kristal Putih}

Eksplorasi Karakteristik kualitas gula kristal putih yang diproduksi PG Tjoekir Jombang musim giling tahun 2017 ditunjukkan pada Tabel 3. Penyajian karakteristik data yang ditampilkan adalah nilai minimum, maksimum, varian, dan rata-rata karakteristik kualitas ICUMSA dan BJB.
Tabel 3. Eksplorasi Karakteristik Kualitas

\begin{tabular}{|lcrrrr|}
\hline Variabel & Shift & Rata-rata & Varian & Min & Maks \\
\hline ICUMSA & 1 & 192,290 & 7746,180 & 106 & 600,00 \\
\hline BJB & 1 & 0,768 & 0,004 & 0,60 & 0,88 \\
\hline ICUMSA & 2 & 183,970 & 5990,050 & 110,00 & 597,00 \\
\hline BJB & 2 & 0,754 & 0,004 & 0,62 & 0,93 \\
\hline ICUMSA & 3 & 178,820 & 5910,680 & 106,00 & 606,00 \\
\hline BJB & 3 & 0,751 & 0,005 & 0,61 & 1,00 \\
\hline
\end{tabular}

Berdasarkan Tabel 3 diketahui bahwa tidak terdapat perbedaan antar shift dalam memproduksi gula kristal putih. Hal ini dapat dilihat dari nilai varians antar shift yang hamper sama untuk karakteristik kualitas BJB, sedangkan untuk variabel ICUMSA pada shift 1 memiliki nilai variansi yang lebih besar jika dibandingkan shift 2 dan shift 3 .

\section{B. Cek Autokorelasi}

Pengecekan ada atau tidaknya autokorelasi pada karakteristik kualitas dapat menggunakan plot ACF.
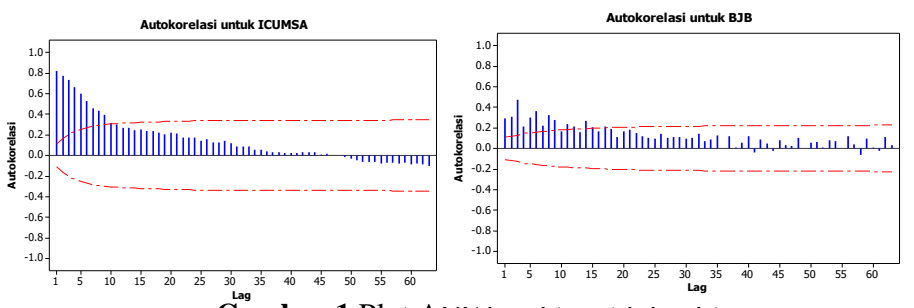

Gambar 1 Plot ACF karakterıstık kualitas

Berdasarkan Gambar 1 diketahui bahwa karakteristik kualitas ICUMSA dan BJB terdapat autokorelasi yang ditunjukkan oleh adanya lag yang keluardari batas signifikansi (Confidence Interval). Hal ini mengindikasikan bahwa antar pengamatan dengan pengamatan yang lain masih terdapat depedensi.

\section{Pemodelan Vector Autoregressive (VAR)}

Model vector autoregressive merupakan salah satu model yang digunakan untuk mendeskripsikan hubungan antara beberapa variabel time series. Pemodelan dapat dilakukan ketika data sudah stasioner dalam varian dan rata-rata, Pengujian stasioner dalam varian dengan menggunakan transformasi Box-cox, sedangkan untuk stasioner dalam ratarata di uji dengan ADF. Diperoleh hasil bahwa karakteristik kualitas ICUMSA sudah stasioner dalam rata-rata karena UCL dan LCL memuat angka 1 atau Rounded Value sebesar 1 dan untuk karakteristik kualitas BJB belum stasioner dalam ratarata sehingga dilakukan transformasi. Pengujian stasioner dalam rata-rata dengan menggunakan uji Augmented DickeyFuller menunjukkan hasil bahwa semua karakteristik kualitas sudah memenuhi asumsi.

\section{Penentuan Orde Vector Autoregressive (VAR)}

Semua karakteristik kualitas ICUMSA dan BJB telah memenuhi asumsi stasioner terhadap varians dan rata-rata, maka dapat dilanjutkan dengan menduga model awal VAR menggunakan plot MPACF. Dalam menentukan orde VAR dapat menggunakan plot MPACF yang ditunjukkan pada Gambar 2 sebagai berikut. 


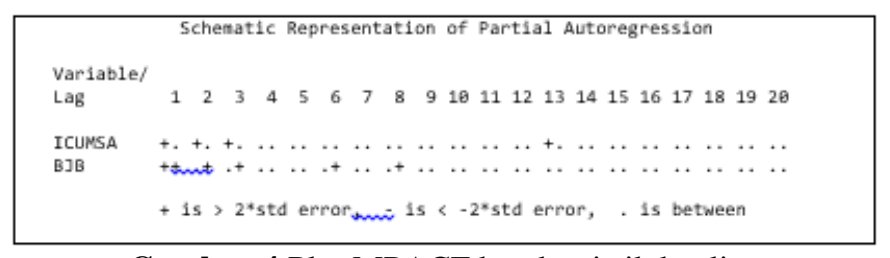

Gambar 4 Plot MPACF karakteristik kualitas

Gambar 4 menunjukkan bahwa pada lag 1, 2, 3, 6, 8, 13 terdapat simbol (+), sehingga dapat diduga model VAR memuat lag-lag tersebut, Penentuan orde VAR dapat menggunakan minimum information criterion.

Tabel 4 Minimum Information Criterion

\begin{tabular}{|c|c|c|c|c|c|c|}
\hline Lag & $\begin{array}{c}\text { MA } \\
(0)\end{array}$ & $\begin{array}{c}\text { MA } \\
(1)\end{array}$ & $\begin{array}{c}\text { MA } \\
(2)\end{array}$ & $\begin{array}{c}\text { MA } \\
(3)\end{array}$ & $\begin{array}{c}\text { MA } \\
(4)\end{array}$ & $\begin{array}{c}\text { MA } \\
(5)\end{array}$ \\
\hline AR (0) & $-7,39$ & $-7,44$ & $-7,50$ & $-7,68$ & $-7,72$ & $-7,80$ \\
\hline AR (1) & $-8,12$ & $-8,29$ & $-8,28$ & $-8,36$ & $-8,43$ & $-8,42$ \\
\hline AR (2) & $-8,26$ & $-8,30$ & $-8,35$ & $-8,38$ & $-8,41$ & $-8,42$ \\
\hline AR (3) & $\mathbf{- 8 , 4 8}$ & $-8,45$ & $-8,43$ & $-8,44$ & $-8,43$ & $-8,43$ \\
\hline AR (4) & $-8,46$ & $-8,45$ & $-8,43$ & $-8,44$ & $-8,42$ & $-8,42$ \\
\hline AR (5) & $-8,46$ & $-8,45$ & $-8,42$ & $-8,43$ & $-8,42$ & $-8,40$ \\
\hline
\end{tabular}

Tabel 4 menjelaskan bahwa orde tentang nilai Minimum information criterion terkecil yaitu sebesar $-8,48$ yang terdapat pada lag AR(3) dan MA(0), sehingga dugaan model awal yang terbentuk adalah VAR (3).

\section{E. Estimasi Parameter Model}

Estimasi parameter digunakan untuk membuktikan bahwa model yang terbentuk menghasilkan parameter yang signifikan. Berikut ini adalah tabel estimasi parameter model.

Tabel 5 Estimasi parameter model

\begin{tabular}{ccccc}
\hline $\begin{array}{c}\text { Variabel } \\
\text { input }\end{array}$ & $\begin{array}{c}\text { Para } \\
\text { meter }\end{array}$ & Estimasi & P-value & $\begin{array}{c}\text { Variabel } \\
\text { output }\end{array}$ \\
\hline & $\phi_{010}$ & 1,01474 & 0,0001 & 1 \\
\cline { 2 - 5 } ICUMSA & $\phi_{111}$ & 0,36408 & 0,0001 & ICUMSA(t-1) \\
\cline { 2 - 5 } & $\phi_{211}$ & 0,17706 & 0,0014 & ICUMSA(t-2) \\
\cline { 2 - 5 } & $\phi_{311}$ & 0,27536 & 0,0001 & ICUMSA(t-3) \\
\cline { 2 - 5 } & $\phi_{312}$ & 0,26255 & 0,0342 & BJB(t-3) \\
\hline \multirow{3}{*}{ BJB } & $\phi_{020}$ & $-0,32921$ & 0,0001 & 1 \\
\hline & $\phi_{121}$ & 0,03958 & 0,0077 & $\operatorname{ICUMSA(t-1)}$ \\
\cline { 2 - 5 } & $\phi_{222}$ & 0,16350 & 0,0014 & $\mathrm{BJB}(\mathrm{t}-2)$ \\
\hline
\end{tabular}

Tabel 5 menerangkan bahwa semua parameter telah signifikan setelah dilakukan restrict. Hal itu dapat diketahui dari P-value yang lebih kecil dari 0,05. Betuk matematis model VAR(3) dapat dituliskan sebagai berikut.

$$
\dot{X}_{t}=\phi_{1} \dot{X}_{t-1}+\phi_{2} \dot{X}_{t-2}+\phi_{3} \dot{X}_{t-3}+a_{t}
$$

$\begin{aligned} {\left[\begin{array}{l}\dot{X}_{1, t} \\ \dot{X}_{2, t}\end{array}\right]=} & {\left[\begin{array}{c}1.01474 \\ -0.32921\end{array}\right]+\left[\begin{array}{cc}0.36408 & 0.03958 \\ 0 & 0\end{array}\right]\left[\begin{array}{c}\dot{X}_{1, t-1} \\ \dot{X}_{2, t-1}\end{array}\right]+\left[\begin{array}{cc}0.17706 & 0 \\ 0 & 0.16350\end{array}\right]\left[\begin{array}{c}\dot{X}_{1, t-2} \\ \dot{X}_{2, t-t}\end{array}\right.} \\ & +\left[\begin{array}{cc}0.27536 & 0 \\ 0.26255 & 0.39272\end{array}\right]\left[\begin{array}{c}\dot{X}_{1, t-3} \\ \dot{X}_{2, t-3}\end{array}\right]\end{aligned}$

Selanjutnya dilakukan pemeriksaan diagnosa yaitu memeriksa dan menguji apakah residual memenuhi asumsi white noise dengan uji Portmanteau.

Tabel 6 Uji Portmanteau

\begin{tabular}{lllll}
\hline Lag ke & \multicolumn{1}{c}{$\mathrm{Qk}$} & $\mathrm{df}$ & $\chi_{(0.05 ; d f)}^{2}$ & $P$-value \\
\hline 4 & 8,67 & 4 & 9,4877 & 0,0699 \\
\hline 5 & 11,98 & 8 & 15,5073 & 0,1523 \\
\hline 6 & 14,54 & 12 & 21,0261 & 0,2678 \\
\hline 7 & 19,86 & 16 & 26,2962 & 0,2268 \\
\hline 8 & 28,92 & 20 & 31,4104 & 0,0894 \\
\hline 9 & 33,96 & 24 & 36,4150 & 0,0854 \\
\hline 10 & 35,2 & 28 & 41,3371 & 0,1642 \\
\hline 11 & 40,66 & 32 & 46,1943 & 0,1403 \\
\hline 12 & 42,55 & 36 & 50,9985 & 0,2098 \\
\hline 13 & 45,74 & 40 & 55,7585 & 0,2459 \\
\hline 14 & 52,21 & 44 & 60,4809 & 0,1850 \\
\hline 16 & 59,35 & 48 & 65,1708 & 0,1261 \\
\hline 17 & 60,89 & 52 & 69,8322 & 0,1864 \\
\hline 18 & 71,26 & 60 & 79,0819 & 0,1516 \\
\hline 19 & 73,2 & 64 & 83,6753 & 0,2018 \\
\hline 20 & 75,01 & 68 & 88,2502 & 0,2618 \\
\hline
\end{tabular}

Berdasarkan hasil uji portmanteau yang disajikan pada Tabel 6 diperoleh nilai statistik uji Qk kurang dari $\chi_{(0.05 ; d f)}^{2}$ atau $p$-value lebih dari 0.05 yang menjelaskan bahwa gagl tolak $\mathrm{H}_{0}$ dan dapat disimpulkan bahwa residual data memenuhi asumsi white noise.Ppengujian distribusi normal multivariat diperoleh nilai $p$-value sebesar 0.1653 lebih besar dari 0.05 , yang berarti gagal menolak $\mathrm{H}_{0}$ yang berarti residual telah memenuhi asumsi distribusi normal multivariat.

\section{F. Pengendalian Kualitas Gula Kristal Putih}

Pada kasus diagram kontrol multivariat berbasis model time series maka residual masing - masing karakteristik kualitas yang dilakukan pengujian korelasi dan distribusi multivariat normal.

\section{Pengujian Asumsi korelasi}

Asumsi yang harus dipenuhi adalah korelasi antar karakteristik kualitas dan distribusi normal multivariat. Pengujian distribusi normal multivariat pada residual telah dilakukan pada tahapan pemodelan VAR yang diperoleh keputusan gagal tolak $\mathrm{H}_{0}$ yang berarti bahwa data telah berdistribusi Normal multivariat. Pengujian korelasi residual menggunakan uji korelasi Pearson didapatkan nilai p-value sebesar 0,009 lebih kecil jika dibandingkan dengan alpha 0,05 sehingga di dapatkan keputusan tolak $H_{0}$ yang mengartikan bahwa terdapat korelasi antar residual karakteristik kualitas.

\section{Analisis variabilitas proses gula kristal putih}

Pada tahap ini dilakukan untuk mengendalikan variabilitas proses yang berlangsung di PG Tjoekir Jombang selama musim giling periode tahun 2017. Pada tahun 2017 PG Tjoekir Jombang beroperasi selama kurang lebih 4 bulan dari bulan 
juli-Oktober. Berikut ini adalah hasil monitoring variabilitas proses produksi gula kristal putih menggunakan diagram kendali $\mathrm{M}$.

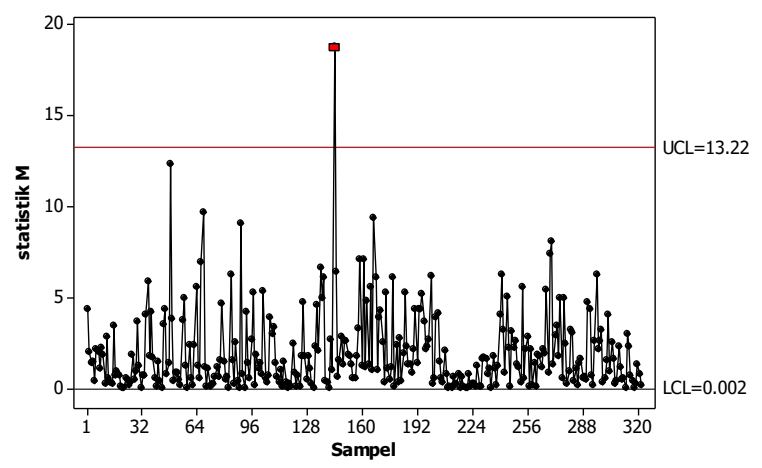

Gambar 5 Diagram kendali M

Berdasarkan Gambar 5 dapat diketahui bahwa terdapat pengamatan yang berada di luar batas kendali atas, Pengamatan yang berada diluar batas kendali adalah pada subgrup ke 145 yaitu pada shift 1. Disimpulkan bahwa variablitas proses produksi gula kristal putih di PG Tjoekir Jombang pada musim giling tahun 2017 belum terkendali secara statistik.Hal ini diperlukan identifikasi masalah yang menjadi penyebab utama proses tidak terkendali, sebelum dilakukan pengamatan selanjutnya.

\section{Analisis rata-rata proses gula kristal putih}

Setelah dilakukan perbaikan pada diagram kendali $\mathrm{M}$ dengan mengeluarkan pengamatan ke 145 . variabilitas proses gula kristal putih terkendali secara statistik. Selanjutnya adalah melakukan analisis untuk memonitoring rata - rata proses produksi gula kristal putih. Berikut ini adalah hasil monitoring rata - rata proses produksi gula kristal putih di PG Tjoekir Jombang dengan menggunakan diagram kontrol $\mathrm{T}^{2}$ Hotelling Individu.

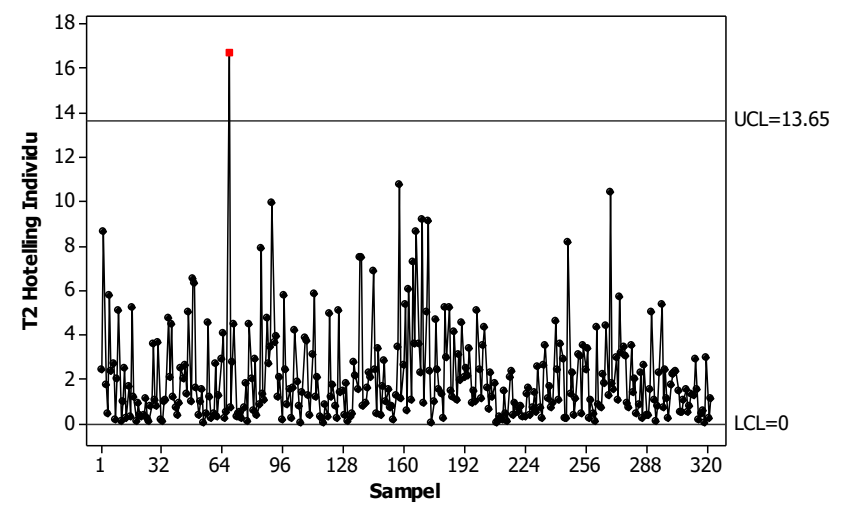

Gambar 6 Diagram kendali $\mathrm{T}^{2}$ Hotelling Individu

Pada Gambar 6 diperoleh nilai batas kendali atas sebesar 11,65 dan batas kendali bawah sebesar 0 dan dapat diketahui bahwa ada pengamatan yang keluar dari batas kendali atas yaitu pada subgroup ke 68 yang disebabkan oleh kerusakan komponen mesin di stasiun gilingan. Dapat disimpulkan bahwa rata-rata proses produksi gula kristal putih belum terkendali secara statistik.

\section{G. Identifikasi Proses tidak terkendali}

Pada proses produksi diketahui bahwa terdapat 5 faktor penyebab suatu data pengamatan tidak terkendali dalam proses produksi gula kristal putih di PG Tjoekir Jombang yaitu faktor tenaga kerja, lingkungan, bahan baku, pengukuran, dan mesin. Faktor tenaga kerja dapat disebabkan oleh ketidakdisiplinan para pekerja dan tingkat kemampuan antar pekerja berbeda. Faktor lingkungan dapat disebabkan oleh adanyan gangguan listik yang padam. Faktor bahan baku yang dapat disebabkan oleh material yang digiling memiliki kualitas yang tidak sesuai dengan standar yang telah ditetapkan oleh pabrik gula seperti usia tebu yang terlalu tua atau masih muda, kondisi tebu kotor atau kurang dibersihkan dan disebabkan oleh jenis tebu yang berbeda.

Faktor mesin yang merupakan faktor utama penyebab proses tidak terkendali. Kerusakan mesin dapat disebabkan oleh ketidaksesuaian setting awal pada saat masa perbaikan mesin yang biasa dilakukan setelah masa musim giling dan berlanjut sampai mendekati musim giling. Masa perbaikan mesin giling terjadi pada bulan November hingga bulan Mei setiap tahunnya ketika akan mendekati musim giling pada periode selanjutnya. Selain itu ketidaksesuaian yang disebabkan oleh faktor mesin juga dapat dipengaruhi oleh maintenance (perawatan) mesin dimana mesin-mesin yang digunakan mayoritas sudah tua sehingga diperlukan kalibrasi sebelum menggunakannya. Faktor pengukuran dapat disebabkan kesalahan pembacaan nilai pada alat ukur dimana ada beberapa alat ukur yang digunakan dalam menghitung karakteristik kualitas seperti refraktometer yang digunakan untuk mengukur warna larutan ICUMSA selain itu faktor yang lain juga dapat disebabkan oleh kurang telitinya pekerja dalam melakukan pengukuran dan pengambilan sampel data. Dari kelima faktor penyebab tersebut ada 3 faktor utama yaitu faktor pengukuran, mesin dan bahan baku merupakan faktor yang paling berpengaruh terhadap ketidaksesuaian proses produksi gula kristal putih di PG Tjoekir Jombang pada musim giling 2017.

\section{KESIMPULAN DAN SARAN}

Berdasarkan hasil analisis dan pembahasan yang telah dilakukan diketahui hasil bahwa antar shift tidak memberikan perbedaan yang signifikan dalam produksi gula kristal putih, Pemodelan time series terbaik yaitu dengan menggunakan model VAR (3) yang telah memenuhi semua asumsi. Hasil diagram kendali $\mathrm{M}$ dan $\mathrm{T}^{2}$ Hotelling Individu yang dibentuk berdasarkan residual diperoleh bahwa produksi gula kristal putih di PG Tjoekir Jombang belum terkendali secara statistik dari variabilitas dan rata-ratanya juga masih terdapat pengamatan yang keluar. Hasil inspeksi yang dilakukan ternyata terdapat kerusakan pada mesin yaitu pada pengamatan ke 145.

Saran yang dapat diberikan kepada PG Tjoekir Jombang untuk musim giling pada tahun 2018 adalah melakukan perbaikan proses khususnya pada mesin dengan melakukan pengecekan terhadap mesin yang akan digunakan secara berkala dan mengganti komponen yang sering mengalami kerusakan. Salah satunnya adalah melakukan pengecekan terhadap kondisi rantai yang digunakan dan setting mesin yang 
mana dapat menyebabkan produksi gula kristal putih yang tidak terkendali secara statistik. Selain itu pihak manajemen PG Tjoekir Jombang perlu memperhatikan faktor lain yang dapat menyebabkan ketidaksesuain proses produksi.

\section{DAFTAR PUSTAKA}

[1] Kemendag, "Pemerintah Akan Impor Gula 1 Juta Ton Lebih," Kompas, 2017. [Online].

[2] J. H. Payne, Unit Operations In Cane Sugar Production, vol. 4, Amsterdam: Elsevier Science Publishing Company Inc, 1982.

[3] BSN, Gula Kristal Bagian 3 Putih, Jakarta: Badan Standardarisasi Nasional, 2010.

[4] E. Widiaswanti, "Penggunaan Metode Statistical Quality Control (SQC) Untuk Pengendalian Kualitas Produk," Industri Inovatif, vol. 4, no. 2, pp. 6-12, 2014.

[5] D. C. Montgomery, Statistical Quality Kontrol, United States: John Wiley \& Sons, Inc., 2009.

[6] L. C. Alwan and H. V. Roberts, "Time Series Modeling for Statistical Process Control," Journal Of Bussiness \& Economic Statistics, vol. 6, no. 1, pp. 87-95, 1988.

[7] J. E. Jarrett and X. Pan, "Vector Autoregression and Monitoring Multivariate Autocorrelated Processes," Journal Computational \& Data Analysis, vol. 51, pp. 3862-3870, 2006.

[8] R. S. Putri, Analisis Pengendalian Kualitas Tetets Produksi PG Pesantren Baru Kediri Menggunakan Diagram Multivariate Berbasis Model Time Series, Surabaya: Jurusan Statistika Institut Teknologi Sepuluh Nopember, 2015.

[9] W. W. S. Wei, Time Series Analysis, New York: Addison Wesley, 2006.

[10] M. Khoo and S. Quah, "Multivariate Control Chart For Process Dispersion Based On Individual Observations," Journal Quality Engineering, vol. 15, no. 4, pp. 639-642, 2003. 